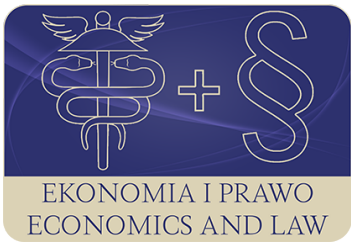

EKONOMIA I PRAWO. ECONOMICS AND LAW

Volume 19, Issue 2, June 2020

p-ISSN 1898-2255, e-ISSN 2392-1625

www.economicsandlaw.pl

EKONOMIA I PRAWO
ECONOMICS AND LAW

ORIGINAL ARTICLE

received 30.03.2019; revised 20.01.2020; accepted 30.06.2020

Citation: Chłąd, M. (2020). Analysis of stakeholders' knowledge and attitude towards socially responsible entities. Ekonomia i Prawo. Economics and Law, 19(2): 217-232.

doi:10.12775/EiP.2020.015.

\title{
Analysis of stakeholders' knowledge and attitude towards socially responsible entities
}

\author{
MONIKA CHEĄD \\ Czestochowa University of Technology, Faculty of Management, Chair of Logistics and International \\ Management, ul. Armii Krajowej 18B, 42-200 Częstochowa, Poland \\ $\square$ monika.chlad@wz.pcz.pl \\ (D) orcid.org/0000-0002-9925-6000
}

\begin{abstract}
Motivation: There is no single, indisputable definition of corporate social responsibility (CSR), neither in the subject literature nor the practical sphere. Different circles of interest have their own interpretation of CSR, though the evolution of the term can be clearly seen. Knowledge of the motivation of business entities implementing this concept could bring a worthy addition to its definition.

Aim: The purpose of this article is to analyze the opinions of respondents and their attitudes towards social responsibility, and whether the involvement of companies affects

their choices as consumers and employees. In the survey I focused on three aspects: knowledge and understanding of the concept of CSR, the impact of CSR on the attitudes and choices of consumers and employees, as well as the reception and evaluation of these activities by the surveyed people.

Results: The research included a group of people who answered questions about CSR and they assessed the involvement of companies which influence consumers' and producers' choices.
\end{abstract}

Keywords: corporate social responsibility; the role of stakeholders

JEL: M10; M14; G39 


\section{Introduction}

Corporate Social Responsibility (CSR) is a philosophy of management according to which the enterprise is responsible for the impact which it has on a natural environment and the society. Companies in their strategy should take into consideration not only the economic, but also social, environmental and ethical issues. This attitude has grown more and more popular and now it became a common policy among international enterprises. In Poland, our national companies start to appreciate the strategy of social involvement, but still the necessity of its implementing is not so obvious. The difference in the phases in which the CSR concept is found in relation to various entities is that social corporate responsibility becomes not so much an added value today as a prerequisite for the operation of multinational corporations. Consumers are becoming more and more aware and demanding - they are not only interested in the product, but also in what conditions it was produced, whether employees and suppliers were honestly paid and whether the company protects the environment. The goal of this essay is to analyse respondents' opinions and what attitude they have towards social responsibility and if the involvement of companies has an impact on their choices as consumers and employees. Three aspects were taken into consideration during the preparation of the survey: knowledge and understanding of the term CSR, the impact of CSR activities on the attitudes and choices of consumers and employees, as well as on the reception and evaluation of these activities by the respondents.

\section{Motivation and barriers to the implementation of the corporate social responsibility concept}

The concept of corporate social responsibility, as every other idea, has its advantages and disadvantages its followers and opponents. Apart of noble assumptions, it is not an element of unilateral and conflict-free interest. Some consider the CSR concept as a missing element of business management, while others see this strategy as a threat to the rules of the free market. Surely, enterprises which decide to implement this strategy have some benefits because of this fact but they have to pay some costs. It is crucial to analyse motives that decide whether or not to take actions in the area of CSR (Piersiala \& Tylec, 2017, pp. 321-320).

The most famous opponent of CSR is the Nobel laureate in economics, Milton Friedman. According to him, an enterprise is created to generate long-term profits and benefits, not to deal with social problems, that is why the management of companies has no skills nor experience in this field. Moreover, he shows that corporate social responsibility creates costs, which leads to lower profits or increased price, and thus costs are passed on to the customer / consumer.

The next argument against CSR is the uncontrolled increase in the importance of international corporations through interference in the sphere of activ- 
ity of a given country. This trend is already noticeable in the form of transferring rights and obligations previously reserved for the state to the benefit of corporations (Bryl, 2010, p. 463). Despite this, enterprises are motivated to actions connected with realizations of assumptions of a social responsibility. One of the motives is saturation of markets and a corresponding increase in competition from other companies. In the past, corporations had possibilities to expand on many new markets, and did not have to make such effort in order to hold their position in the market. The growth of the number of enterprises and their internationalization caused a significant change in the market situation; corporations pursuing the acquisition strategy had to pursue the strategy of maintaining already owned markets, based primarily on building customer loyalty. In the situation when among clients the interest in social responsibility is growing among clients, the interest must grow among enterprises as well (Nakonieczna, 2004 , p. 285). We can distinguish six basic benefits from corporate social responsibility, as shown on scheme 1 .

Cost reduction is possible by limiting the energy and material consumption of production and services in order to minimize the harmful impact on the natural environment (Wójcik-Jurkiewicz, 2016, pp. 145-146). In addition, CSR activities aimed at employees increase their motivation, commitment and productivity while reducing the turnover ratio. The increase in revenues is the result of an increase in the demand for products and services delivered with respect for the natural environment, and thus actions from the field of CSR allow the company to gain new clients, and increase the loyalty of the present (Sala, 2005, p. 33). Understanding the expectations of the most important stakeholder groups allows managers to better define key risk areas and thus more effective risk management by preventing problems leading to crises, as shown in scheme 2 . (Epstein, 1998, p. 31).

An undisputed benefit of social responsibility is a positive impact on reputation. Clients and consumers appreciate the actions of a company, and are more loyal towards a responsible brand. Easier access to capital is achieved because of larger lenders' trust and lower investment risk. Undoubtedly, the development of the local environment favours the development of the company. In response to social needs, the company's CSR activity may include typically philanthropic activities, help a specific group of those in need, or involve investments that bring a change in the functioning of the environment (Zielińska, 2013, pp. 289-292). While making analysis of CSR profitability, the key is to assess the results of actions which the enterprise achieved due to the corporate social responsibility strategy (Kuraś \& Turek, 2016, pp. 278-280). The more effort is taken at the beginning of implementing CSR into the enterprise strategy, the more complete and better in quality will be the analysis. Table 1 presents the division of CSR benefits into financial and non-financial, using the break-down of indicators into qualitative and quantitative ones.

The profits from CSR are opposed to costs connected with this strategy. Implementation of CSR by enterprises determines incurring specific expenditures 
of different resources: financial, human, etc. The costs of social responsibility can be assigned to two groups (Mazur-Wierzbicka, 2012, p. 44):

- one-time costs (one-off subsidies, e.g. a donation given by a company to flood victims and investments such as machines, which may be related to the launch of a new eco-product line);

- costs incurred on a continuous basis (costs of regular grants and subsidies e.g. granted by the enterprise under the social program, all fees e.g. for Eco-labels, certificates, personnel costs, costs of training services, materials, products and services related to the company's activities).

Thus, costs of CSR should be assumed as costs of particular actions which resulted from implemented strategy. Many Polish entrepreneurs consider the use of CSR as something additional, not connected with general functioning, the enterprise's strategy. In time of the crisis they concentrate on limiting the costs, while CSR implementation needs particular investments. Following this way of thinking, costs of CSR can be redundant for this group of entrepreneurs. This attitude results from the lack of knowledge and awareness of what it actually means to be a socially responsible enterprise. Investment in CSR may be compared to entering a new market. A well-prepared and implemented strategy brings tangible economic benefits while respecting the needs and expectations of various stakeholder groups (Mazur-Wierzbicka, 2012, p. 47).

There are two main reasons for implementing the concept of corporate social responsibility (Zielińska, 2013, pp. 290-291):

- creating new opportunities and increasing benefits,

- better control over the risk of threats.

- CSR may be something more than a risk of additional costs, a duty or a good deed; it may be a source of chances, innovations and competitive advantage (Porter \& Kramer, 2006, pp. 78-92).

It might be assumed that an increase of interest of social responsibility results from actions of many non-governmental organizations. They create a group of attentive observers of corporation's activity, particularly in case of possible contradictions between their behavior and the ideas of social responsibility. These contradictions occur mainly in cases of the use of a privileged position of corporations against weaker entities. Non-governmental organizations have a strong ability to detect unethical corporate behavior and, through media, are able to disseminate them on a global scale. Public disclosure of corporate fraud may have significant consequences. Criticism from the public, unfavourable comments in the press and media have a significant impact on the reputation and confidence in the company. Detected abuses can become a reason for lawsuits which can additionally provoke worse opinion and high financial costs. The most severe effect of socially irresponsible behaviors is the boycott of company's (Onufer, 2006, p. 96). The main reasons for relatively low interest of Polish enterprises in corporate social responsibility can be considered in many respects. Every case should be considered individually, taking into consideration many factors such as: the specificity of the industry, area, size of the enterprise, range 
of operations, legal, social and political conditions in which the entity operates. We can distinguish a few basic factors which influence the low interest in the idea of CSR which are smaller or larger barriers for particular enterprises. These are for example: methodological, theoretical and practical factors, i.e. the lack of specific guidelines, discrepancies in interpretations and ambiguous definitions result in a clear deterrence of entrepreneurs to implement CSR. The level of adaptation of the concept of corporate social responsibility depends on differences between the social and economic level of the economic situation of the country, adherence to the principles of business ethics. The fundamental barrier of implementing CSR strategy an enterprise is a lack of knowledge in that field. Only recently has the problem of corporate social responsibility started to be present at universities, and promoted more broadly among small and medium-sized enterprises (Mazur-Wierzbicka, 2012, p. 73).

Globalization is causing a constant growth of CSR awareness, not only among enterprises but also among clients. Awareness of consumers provoke companies to implement CSR strategy which allows to offer an added value to clients. It is increasingly recognized that the commitment to provide sustainability benefits not only the society, but also companies. Therefore, regardless of the disadvantages and barriers in implementing social responsibility, companies will increasingly use this concept, which becomes the foundation for building trust among stakeholders, and this can be the main source of competitive advantage.

\section{Methods}

The survey was conducted in three areas regarding the knowledge and understanding of the term CSR, the impact of CSR activities on the attitude of consumer and employee choices, as well as the appropriate reception of social responsibility activities by the respondents. The study, the analysis of which was published, was conducted at the turn of 2018 and 2019, among consumers in the form of a direct interview and an auditorium survey to reach the appropriate group. The total size of the research sample used for the analysis was 200 people. The research sample was determined when answering the following research questions:

- Do you know the term CSR (Corporate Social Responsibility)?

- Would you still choose the product of a socially responsible company if it were more expensive than a substitute for another company?

- What is your opinion about CSR activities?

- What are the CSR practices towards the employee?

The above assumptions allowed to draw attention to the elements contained in the article. 


\section{The theory of stakeholders as the basis for the concept of corporate social responsibility}

The theory of stakeholders is a basis of the CSR concept. It was formulated by R. Edward Freeman in 1984 in the book Strategic management: a stakeholder approach. Stakeholders include any group or entity (institution, but also natural environment) which can influence or is influenced by the company's operations through its products, strategies, management systems and procedures, manufacturing processes (Mazur-Wierzbicka, 2012, p. 74). This is the so-called 'wide definition'. In the literature, we can also find a narrow view of stakeholders. While Freeman's theory is identified as an ethical element, the author himself declared the affiliation of the stakeholder model to management theory. He wrote: 'the stake-holder model presented here is prescriptive in the sense that it requires corporation managers to act in a rational way. If you want to manage effectively, then you have to take stakeholders into account in some orderly way is a prescription, but it is fundamentally different from You should communicate with those who criticize the corporation' (Freeman, 1984, p. 48). Although Freeman, in his early works was an opponent to CSR, his theory contributed to development of this concept, of which an inherent part is seeing the enterprise from the perspective of different interest. This chain of connections and dependencies with the entities of the internal and external environment is convergent with the system approach. Systems theory shows, that - just as biological organisms depend on elements of the ecosystem - enterprises must be aware of the entities with which they are interdependent, and acquire the ability to adapt to the changing environment (Mikołajczyk, 1999, p. 54). Freeman divided stakeholders to primary and secondary, which is presented in table 2.

Thus, main and primary stakeholders are the units and groups which directly affect the functioning of the company with which it has formal contracts or agreements. Secondary stakeholders do not conduct any transactions with the company, so it can be said that they are not necessary for its functioning. They can influence or feel the influence of the organization's actions because of its strategy, products, procedures and management systems, although the sole existence of the company does not directly depend on them (Jastrzębska, 2011, pp. 97-100). Because of the character of relation between stakeholders and the organization we can divide stakeholders into three groups (Anuszkiewicz \& Marona, 2012, p. 36):

- substantial stakeholders,

- contracted stakeholders,

- contextual stakeholders.

The first group are those who co-create the company with their knowledge, work, competences, and capital, so they are owners, shareholders or employees. The character of relation between these groups and a company is substantial - without them the company could not exist. Contracted stakeholders are clients, competitors, suppliers and co-operators of the enterprise. There is 
a character of a formal contract between them. The third group consists of different communities - local, state or even global. Contextual stakeholders are therefore all social and governmental institutions that play a fundamental role in building the company's 'good name' and in obtaining acceptance for its activities (Ricart et al., 2005, pp. 35-37). All of this stakeholders' divisions make it easier to create strategies for acting on them. Not every group of stakeholders is equally important for the company, so the actions towards them will also differ as shown in table 3.

The minimum of efforts the enterprise should lead towards stakeholders who have a small influence and at the same time do not show the interest towards the enterprise. The stakeholders' theory has a managerial character because it not only defines the character of relationships between enterprises and their stakeholders but also suggests particular ways of behaviors which are the best for organization's activities (Hąbek, 2010, p. 81).

Corporate social responsibility is said to be a 'concept orientated on stakeholders'. Freeman called CSR as 'the missing link of capitalism' (Rotengruber, 2017, pp. 66-68). Thus, this strategy fills in the gaps in the current form of conducting business in which there were no social activities. The theory of stakeholders in the context of social responsibility leads to a sustainable building of the value of an organization focused on stakeholders, not limited only to the owners and shareholders of the company. Corporate governance becomes the supervision exercised by all interested parties, hence it is a broader concept than strictly owner's supervision (Telega, 2012, p. 291). The strategy of business orientated on stakeholders is more and more popular, but there are some critical voices undermining the validity of this approach in management. Defining and measurement of qualities for stakeholders is unclear because their variety is too wide. For the management of enterprises only actions to achieve high shareholder returns are understandable. Due to the complex nature of the preferences and expectations of other stakeholders, enterprises have problems in directing appropriate actions to them

\section{The importance of corporate social involvement for consumers and employees}

In this part the goal will be to recognize respondents' attitudes towards information about the social involvement of companies. The basic question is, if the CSR's actions have an impact on our consumer choices or decisions made on a labor market. If we talk about responsible actions of companies, we should wonder if it meets responsible consumption. While choosing a particular product, we support a company which produced it. $35 \%$ of respondents take into consideration the information about social involvement of companies while choosing products (by summing two last answers) (chart 1). The same number thinks that the information does not have any impact on their choices. $8 \%$ does not trust this information and $22 \%$ does not see it. It can be an evidence that so- 
cially responsible activities are not communicated in the right way. In this way, consumers can ignore the element of corporate social commitment, or consider it only as a marketing gimmick.

On the chart 2 we can see that together $79 \%$ of people are willing to buy a product of a socially responsible company if its price is not higher and the quality not lower than the substitute of another company. It is a positive signal, but in practice, while choosing a product we do not have two packages one of which has a label 'the product of a company which is socially responsible'. In the question the situation is easier, what made that $20 \%$ of respondents claimed that it does not matter to them what company stands behind the product offered to them, whereas in the previous question 'indifferent consumers' constituted almost twice as large a group. Taking into consideration earlier observations, a consumer sometimes must make an effort to get to know which company operates in responsible way. Consumers' unawareness is the reason that most often CSR does not determine their choices. Going forward, if almost $80 \%$ of respondents declare the choice of socially responsible company's product then it should be considered if this group is eager to pay more for this product. The results are illustrated in the graph below (the question was NOT asked to the group of respondents who in the previous question replied: 'it does not matter to me' and 'I probably will not choose a product of a socially responsible company').

Chart 3 presents two extracted groups: people who in the previous questions declared to choose the product of socially responsible company for sure and people who are willing to choose this product. We can see that in the first group of respondents $26 \%$ are willing to pay more for a product representing the socially responsible brand, while in the second group the percentage of people declaring such an attitude is half as much. In the second variant of the answer, the price difference was given by the respondents - one that is acceptable to them. The adopted range of $10-25 \%$ shown in the graph is the interval of the values most often given. Some of them were able to pay even more the highest percentage difference in price is $60 \%$. Here, too, we can see the majority of the respondents from the first group. The cheaper product was chosen globally by $28 \%$ of respondents, of which $13 \%$ from the first group and $38 \%$ from the second group.

Chart 4 shows the hierarchy in which respondents set particular actions of CSR addressed to an employee. $30 \%$ of respondents on a first place put wage instruments - bonuses, rewards and pay rises. In turn, 52\% of respondents considered work volunteering the least important to them. It is the only action in this question which is about employees but they are not beneficiaries but co-creators of this activity. On the one hand, the choice of respondents seems to be natural here but on the other hand, we should think if it's just to expect benefits to for ourselves, and but we do not show interest in building these benefits towards others. After assigning weights to particular places, the total hierarchy according to the respondents looks as follows:

- bonuses, rewards and pay-rises; 
- trainings and development;

- the concept of 'work-life-balance';

- dialogue with employees;

- additional health insurance;

- non-pay benefits, aimed at culture, education, sport and others;

- adaptation and integration programs;

- employee volunteering.

The aim of this question was to acquaint respondents with potential bene-fits which an employee can get in a company which realizes CSR directed to the inside of the organization. This is important knowledge in the con-text of the next question.

For $32 \%$ of respondents it is not important if a potential employer is a socially responsible company - the priority is an amount of remuneration. More than a half of respondents is willing to choose an employer who is socially involved if the wage offered by him is not lower than the competitive company. Only $12 \%$ declare that even if the company offers lower remuneration from the competitive company provided that this difference will be in the range of 5-10\%. As in the case of the question about the choice of a product - the respondents also gave the difference in remuneration. We can see that in the case of a product, the range was 10-25\%, here it is definitely lower. The highest given number was $20 \%$ (chart 5). Respondents who had to imagine being an employee in two last questions were more often driven by economic considerations than they were in the role of a consumer. For $88 \%$ of respondents the issue of remuneration is a key to the attractiveness of a particular position, despite getting acquainted with a number of additional benefits - including financial ones - that the employer can offer outside of remuneration. On the other hand, for more than $68 \%$ of respondents these actions are the additional value. Certainly, the activity of companies in the area of social responsibility is not without significance when acquiring employees, although it has a more significant impact on the retention of qualified staff in the company.

\section{Conclusion}

To sum up CSR strategy is can be seen as an alternative for other forms of building a competitive advantage, and using good practices for image purposes does not diminish the benefits that society gains from this strategy. From the point of view of the society, it seems inappropriate to undermine the good intentions of companies, because it can only lead to their discouragement. Because it is impossible to clearly determine the impact of realization of CSR actions on financial profit of the company, it is worth to focus on the effects, not the reasons for running this strategy. Socially involved entities should concentrate more on their consumers' education in order to strengthen their awareness. The consumers by responsible consumption may stimulate the intensification of activi- 
ties carried out in the area of CSR. In this way, we come to the typical 'win-win' situation, which benefits each of the participating parties.

\section{References}

Adamczyk, J. (2009). Spoteczna odpowiedzialność przedsiębiorstw. Warszawa: PWE.

Anam, L., Szul-Skjoeldkrona, E., \& Zamościńska, E. (2012). Jak zyskać na odpowiedzialności? CSR w strategiach spótek gietdowych. Warszawa: CSR info.

Anuszkiewicz, K., \& Marona, T. (2012). Rola interesariuszy w rozwoju przedsiębiorstwa odpowiedzialnego społecznie. Rynek-Spoteczeństwo-Kultura, 1.

Bryl, Ł. (2010). Społeczna odpowiedzialność biznesowa na przykładzie firmy Polska. In M. Matejun, \& M. Szczepańczyk (Eds.), Aktualne problemy zarządzania matymi i średnimi przedsiębiorstwami. Łódź: Politechnika Łódzka.

Epstein, E.M. (1998). Business ethics and corporate social policy. Business \& Society, 37(1). doi:10.1177/000765039803700102.

Freeman, R.E. (1984). Strategic management: a stakeholder approach. Boston: Pitman.

Freeman, R.E., Harrison, J.S., \& Wics, A.C. (2007). Managing for stakeholders: survival, reputation and success. New Haven: Yale University Press.

Hąbek, P. (2009). Społeczna odpowiedzialność przedsiębiorstw jako koncepcja firmy zorientowanej na interesariuszy. Organizacja i Zarządzanie, 2(6).

Jastrzębska, E. (2011). Wprowadzenie do koncepcji CSR i zrównoważonego rozwoju. In J. Reichel (Ed.), Jak uczyć o spotecznej odpowiedzialności i zrównoważonym rozwoju: przewodnik dla nauczycieli. Warszawa : Forum Odpowiedzialnego Biznesu.

Kuraś, M., \& Turek, I. (2016). Bariery wykazywania kosztów prac rozwojowych w sprawozdaniu finansowym. In S. Kowalska, \& J. Rubik (Eds.), Zarządzanie kosztami przedsiębiorstwa w kontekście spotecznej odpowiedzialności biznesu. Częstochowa: Politechnika Częstochowska.

Mazur-Wierzbicka, E. (2012). CSR w dydaktyce, czyli jak uczyć studentów społecznej odpowiedzialności. Szczecin: Stowarzyszenie Kreatywni dla Szczecina.

Mikołajczyk, Z. (1999). Techniki organizatorskie w rozwiązywaniu problemów zarządzania. Warszawa: PWN.

Nakonieczna, J. (2004). Społeczna odpowiedzialność: nowy akcent globalnej strategii przedsiębiorstw międzynarodowych. In E. Haliżak, R. Kuźniar, \& J. Symonides (Eds.), Globalizacja a stosunki międzynarodowe. BydgoszczWarszawa: Oficyna Wydawnicza Branta.

Onufer, A. (2006). Społeczna odpowiedzialność korporacji transnarodowych. Studenckie Prace Prawnicze, Administratywnicze i Ekonomiczne Uniwersytetu we Wroctawiu, 4.

Paliwoda-Matiolańska, A. ( 2014). Odpowiedzialność spoteczna $w$ procesie zarządzania przedsiębiorstwem. Warszawa: C.H. Beck. 
Paliwoda-Matiolańska, A. (2009). Odpowiedzialność spoteczna w procesie zarządzania przedsiębiorstwem. Warszawa: C.H. Beck.

Piersiala, L., \& Tylec, A., (2017). (Nie)odpowiedzialność społeczna specjalnych stref ekonomicznych w Polsce. Scientific Papers of Silesian University of Technology: Organization and Management Series, 102. doi:10.29119/1641-3466.2017.102.26.

Porter, M.E., \& Kramer, M.R. (2006). Strategy and society: the link between competitive advantage and corporate social responsibility. Harvard Business Review, December.

Ricart, J.E., Rodriguez, M.A., Sanchez, P., \& Ventoso, L.(2005). The sustainable enterprise: learning from DJSI leaders. Bilbao: Fundacion BBVA.

Rok, B. (2004). Odpowiedzialny biznes w nieodpowiedzialnym świecie. Warszawa: Akademia Rozwoju Filantropii w Polsce, Forum Odpowiedzialnego Biznesu.

Rotengruber, P. (2017). R. Edward Freeman wobec koncepcji interesariusza: w obronie przekonań normatywnych uczestników życia gospodarczego. Prakseologia, 159.

Sala, S. (2005). Rozwój korporacji transnarodowych w gospodarce światowej. Przedsiębiorczość: Edukacja, 1. doi:10.24917/713.

Telega, A. (2012) Problematyka nadzoru korporacyjnego i jego wplyw na kreowanie wartości organizacji. In . A. Nalepka, \& A. Ujwara-Gil (Eds.), Organizacje komercyjne i niekomercyjne wobec wzmożonej konkurencji oraz wzrastających wymagań konsumentów. Nowy Sącz: Wyższa Szkoła Biznesu.

Wójcik-Jurkiewicz, M. (2016). Idea społecznie odpowiedzialnego biznesu a kształtowanie wyniku finansowego spółki. Studia Ekonomiczne: Zeszyty Naukowe Uniwersytetu Ekonomicznego w Katowicach, 253.

Zielińska, A., (2013). Społeczna odpowiedzialność przedsiębiorstw we współpracy z organizacjami pozarządowymi. Zeszyty Naukowe Uniwersytetu Szczecińskiego: Problemy Zarządzania, Finansów i Marketingu, 30.

\section{Acknowledgements}

Author contributions: author has given an approval to the final version of the article.

Funding: this research was funded by the Czestochowa University of Technology, Faculty of Management statutory sources.

Note: the results of this study were presented at 10th International Conference on Applied Economics Contemporary Issues in Economy (June 27-28, 2019, Torun, Poland). 


\section{Appendix}

\section{Tablel.}

\section{Benefits of corporate social responsibility strategy}

\begin{tabular}{ll}
\hline \multicolumn{1}{c}{ financial } & \multicolumn{1}{c}{ Type of benefits } \\
\hline- increase in brand value & - increased commitment and motivation among employees \\
- cost reduction & - innovation \\
- risk reduction & - new, more effective models of services or processes \\
- turnover increase & - better adaptation to new regulations and better integration with processes \\
- increasing market share & - improved access to capital \\
& - better relations with investors \\
& - social mandate for action \\
& - reputation improvement \\
& - increase in employee productivity \\
& - reduced staff turnover \\
& - reduction in employee absences \\
& - increase in the number of innovation proposals in the company \\
& and the development of new products \\
& - increased efficiency of resource consumption \\
& - increase in production efficiency \\
& - increased distribution efficiency \\
\hline qualitative & Type of the indicator \\
\hline
\end{tabular}

Source: Own preparation based on Anam et al. (2012, p. 23).

Table 2.

Division of stakeholders according to Freeman

\begin{tabular}{ll}
\hline \multicolumn{1}{c}{ Primary stakeholders } & \multicolumn{1}{c}{ Secondary stakeholders } \\
\hline - clients & - government \\
- employees & - media \\
- suppliers & - competitors \\
- local communities & - non-governmental organizations \\
- financial institutions & - organizations defending consume rights \\
\hline
\end{tabular}

Source: Own preparation based on Adamczyk (2009, p. 87), Freeman at al. (2007, pp. 8-9). 
Table 3.

Enterprises and stakeholders' expectations

\begin{tabular}{|c|c|c|}
\hline Stakeholder & Stakeholders' expectations & Enterprise's expectations \\
\hline employees & $\begin{array}{l}\text { - decent employment conditions } \\
\text { and remuneration adequate } \\
\text { to the contribution in enterprise development } \\
\text { - stability of the employment } \\
\text { - lack of discrimination } \\
\text { - allowing self-development } \\
\text { - occupational and health safety }\end{array}$ & $\begin{array}{l}\text { - reporting of the company's activity } \\
\text { and condition } \\
\text { - dialogue with staff and management } \\
\text { - reliable information in the appropriate time } \\
\text { and form } \\
\text { - satisfaction from work } \\
\text { - fulfilment of duties }\end{array}$ \\
\hline owners & $\begin{array}{l}\text { - guarantee of business continuity } \\
\text { - ability to compete } \\
\text { - dividends } \\
\text { - care for the increase in the value of shares } \\
\text { - compliance with the corporate governance } \\
\text { rules }\end{array}$ & $\begin{array}{l}\text { - definition of strategic assumptions } \\
\text { - forecasts for the future } \\
\text { - business risk assessment } \\
\text { - opportunities and threats to the business } \\
\text { - annual CSR reports and balance sheets } \\
\text { - information about mergers and acquisitions }\end{array}$ \\
\hline suppliers & $\begin{array}{l}\text { - stable and lasting relationships } \\
\text { - timely payment of liabilities } \\
\text { - in accordance with the contract, } \\
\text { - adequate remuneration for provided services } \\
\text { and continuity of supply } \\
\text { - maintaining ethics and culture in operations }\end{array}$ & $\begin{array}{l}\text { - building lasting relationships } \\
\text { - prices suitable for the quality of deliveries } \\
\text { and products in operation }\end{array}$ \\
\hline clients & $\begin{array}{l}\text { - services and products of the highest quality } \\
\text { and safety of their use } \\
\text { - respect for customer culture } \\
\text { - high technical parameters of offered products } \\
\text { - professional approach to customer service } \\
\text { - easily accessible and transparent information }\end{array}$ & $\begin{array}{l}\text { - promotion } \\
\text { - building an image on the market } \\
\text { - building a good reputation } \\
\text { - clear and reliable cooperation } \\
\text { - being determined }\end{array}$ \\
\hline society & $\begin{array}{l}\text { - material and non-material contribution } \\
\text { to social life } \\
\text { - creating work places } \\
\text { - respect for the integrity of local cultures } \\
\text { - activities for education and sport } \\
\text { - protection of the environment } \\
\text { - safe business operations }\end{array}$ & $\begin{array}{l}\text { - public reports } \\
\text { - sharing knowledge in the field of } \\
\text { - management and entrepreneurship } \\
\text { - showing good practices } \\
\text { - promoting the principles of social } \\
\text { responsibility }\end{array}$ \\
\hline $\begin{array}{l}\text { environ- } \\
\text { ment }\end{array}$ & $\begin{array}{l}\text { - minimization of harmful impact } \\
\text { on the natural environment } \\
\text { - care for the criteria and requirements } \\
\text { of the environment } \\
\text { - the use of renewable energy sources } \\
\text { - using new technologies }\end{array}$ & - \\
\hline $\begin{array}{l}\text { government } \\
\text { and local } \\
\text { government } \\
\text { authorities }\end{array}$ & $\begin{array}{l}\text { - creating new workplaces } \\
\text { - respecting the law } \\
\text { - innovations } \\
\text { - increase in competitiveness } \\
\text { - participation in the development of the region }\end{array}$ & - active cooperation within the society \\
\hline
\end{tabular}

Source: Own preparation based on Paliwoda-Matiolańska (2014, pp. 62-63). 
Scheme 1 .

Benefits of corporate social responsibility

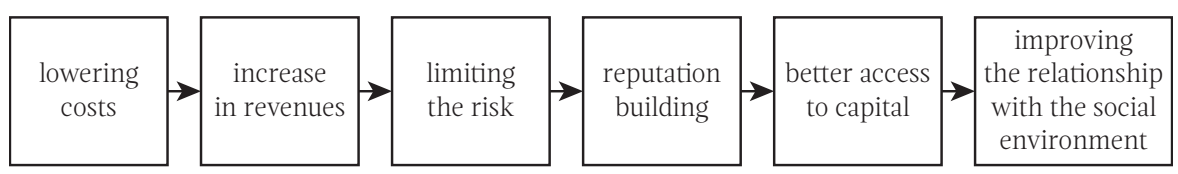

Source: Own preparation based on Rok (2004, pp. 18-19).

\section{Scheme 2.}

Area of corporate social responsibility activities

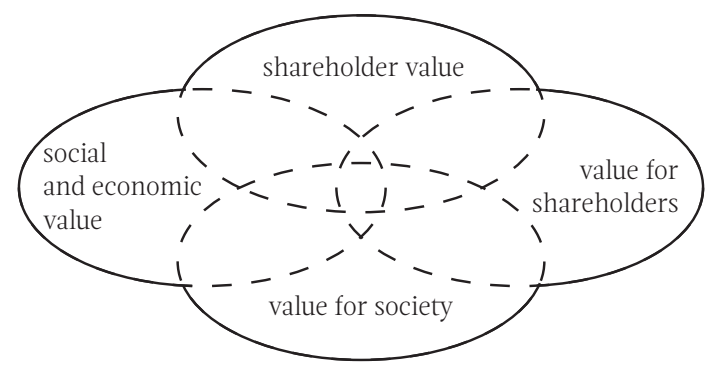

Source: Own preparation based on Paliwoda-Matiolańska (2009, p. 76).

\section{Chart 1.}

The attitude of respondents towards information on corporate social responsibility (in \%)

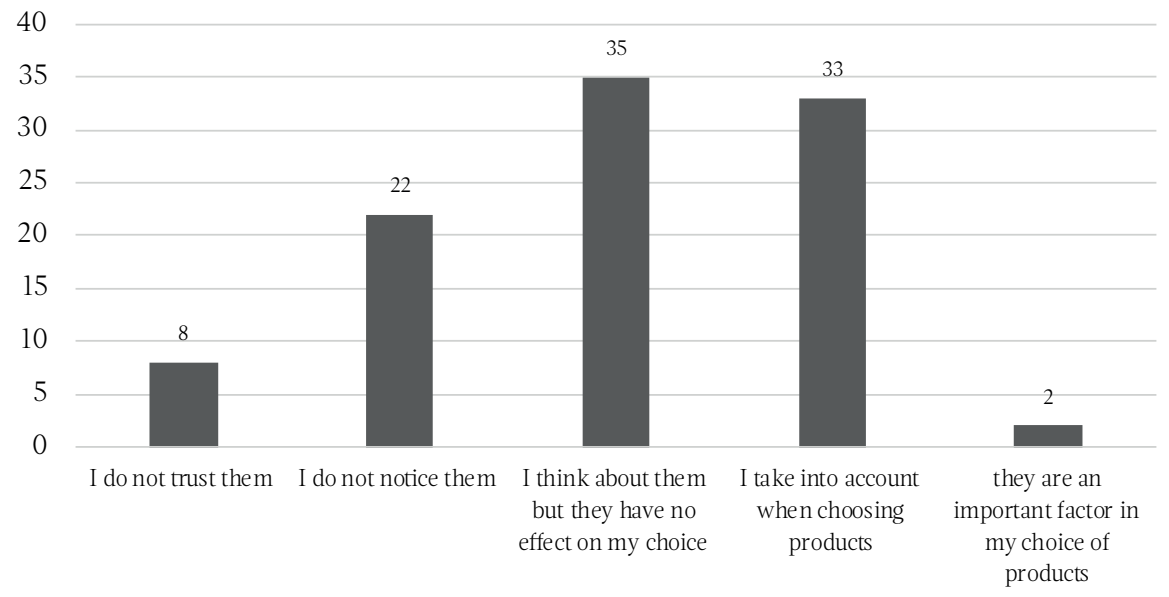

Source: Own preparation. 


\section{Chart 2.}

\section{Consumers' choices (in \%)}

rather, I will not choose the product of a socially responsible company

it does not matter to me

rather, I will choose the product of a socially responsible company

I will definitely choose the product of a socially responsible company

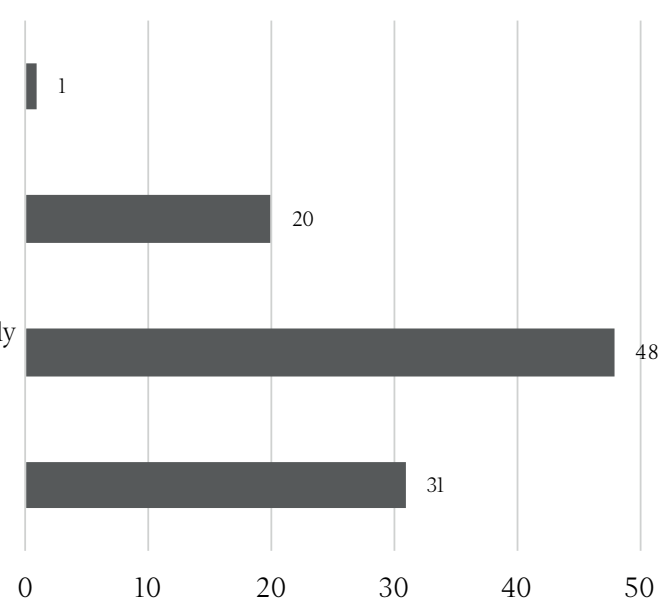

Source: Own preparation.

\section{Chart 3.}

\section{Consumer choices: higher price for CSR (in \%)}

70

60

50

40

30

20

10

0

yes, regardless of the price, I will choose a socially responsible productsocially responsible company
61

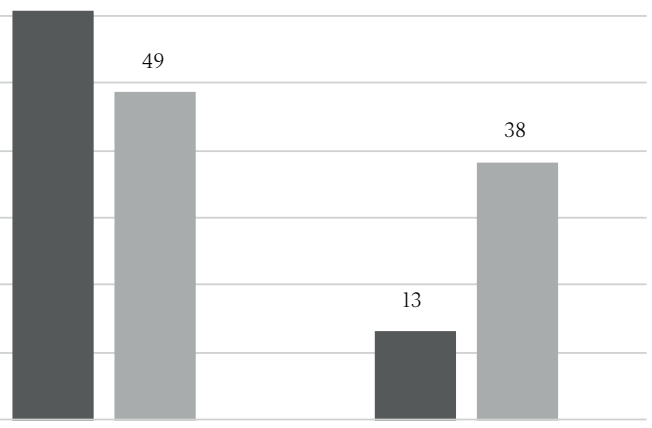

yes, when the price difference was less than $25 \%$

I will choose a cheaper product

Source: Own preparation. 
Chart 4.

CSR practices in relation to the employee (in \%)

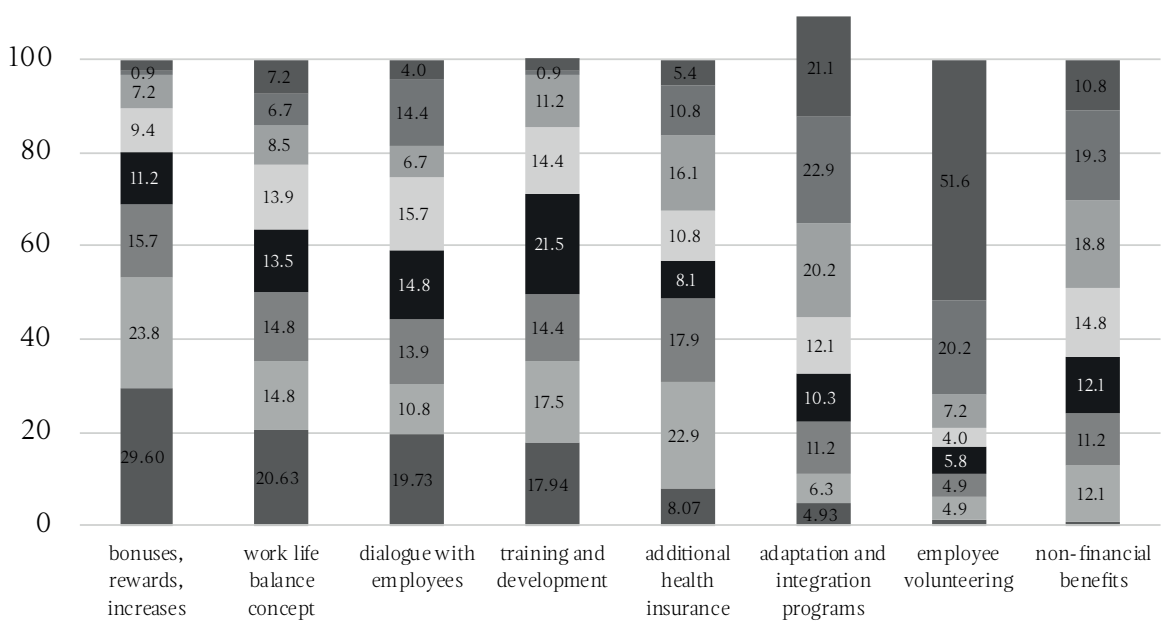

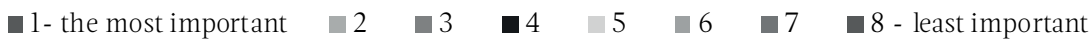

Source: Own preparation.

\section{Chart 5.}

Employees' choices (in \%)

I will choose a socially responsible business, even if it offers lower wages

if both companies offer the same pay, I will choose a socially responsible company

I choose the company that offered me a higher salary

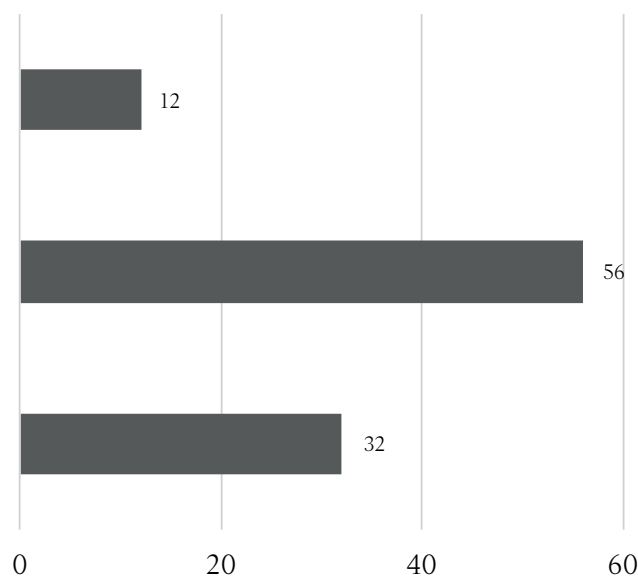

Source: Own preparation. 